Araştırma Makalesi/Research Article

\title{
BULGARISTAN'DA TÜRK AZINLIĞA UYGULANAN ŞİDDET (1944-1989): GALTUNG'UN BARIŞ MODELİ BAĞLAMINDA BİR İNCELEME
}

\author{
THE VIOLENCE APPLIED TO THE TURKISH MINORITY IN BULGARIA (1944-1989): AN \\ INVESTIGATION IN THE CONTEXT OF THE GALTUNG'S PEACE MODEL
}

\author{
Anton Antonov SIMEONOV*
}

Profesör Johan Galtung'un şiddet ve barış anlayışı Uluslararası İlişkiler disiplininde barış ve çatışma gibi temel problemlerin daha kolay anlaşılıp özellikle de çatışma çözümleri bağlamında kalıcı çözümlerin oluşturulmasında önemli rol oynamaktadır. $\mathrm{Bu}$ makale, Bulgaristan Komünist Partisi'nin (BKP) iktidarı döneminde (1944-1989) Bulgaristan'da yaşayan Türk azınlığının durumunu Galtung'un geliştirdiği şiddet ve barış kavramlarının perspektifinden analiz etmektedir. Resmi arşiv belgeleri ve bu belgeliklerden üretilmiş ikincil kaynaklar 1şı̆̆ında ilgili dönemdeki (1944-1989) Türk azınlığının sosyoekonomik ve kültürel durumu analiz edilerek şiddet durumları tespit edilmeye çalışılmıştır. $\mathrm{Bu}$ dönemde Türklerin maruz kaldıkları şiddet/çatışma durumlarının iyi anlaşılması Soğuk Savaş sonrası tesis edilen göreceli pozitif barış hâlinin hak ettiği değeri görmesi açısından son derece önemli olmaktadır.

Anahtar Kelimeler: Bulgaristan, Türk Azınlık, Johan Galtung, Şiddet, Pozitif Barış, Asimilasyon
Abstract

Professor Johan Galtung's understanding of violence and peace plays an important role for understanding the basic problems such as peace and conflict in the International Relations discipline, and in particular, it is important for establishment of permanent solutions in the context of conflict resolution. This article analyses the situation of the Turkish minority living in Bulgaria during the rule of the Bulgarian Communist Party (BCP) (1944-1989), in particular from the perspective of violence and peace concepts developed by Galtung. In order to identify the violence situations, it was analysed the socio-economic and cultural situation of the Turkish minority in the relevant period (1944-1989), in the light of official archival documents and secondary sources reproduced by this archives. A good understanding of the violence/conflict situations, which are experienced by the Turks during this period, is extremely important in terms of seeing the value of relative positive peace, established in the post-Cold War period.

Keywords: Bulgaria, Turkish Minority, Johan Galtung, Violence, Positive Peace, Assimilation

* (iD) Bağımsız Araştırmacı, anton.simeonov86@ gmail.com 


\section{EXTENDED SUMMARY}

Background: Turkish minorities, as a part of the Turkish nation, had to live in different countries as a legacy from the collapse of the Ottoman Empire. However, many of them had annoying images for the hosting countries. This resulted in many troubles for the daily life of these Turkish minorities. One of these minorities is the Turkish minority in Bulgaria. After five centuries of Ottoman rule, the Bulgarian independence comes but hard times for Turkish minority starts. Bulgaria, after gaining its principal autonomy in 1878, uneasy life of Turkish minority begins: forced migrations, expatriations, inner state relocation and oppressions have been the reality for this minority. Especially, when the state has been pushed behind the iron curtain in 1944 until its end in 1989, socio-economic and cultural life of the Turkish minority in Bulgaria became indeed hardly.

Purpose: The purpose of this article is to determine and especially to define the conditions in which Turkish minority has lived during the Bulgarian Communist Party (BCP) rule in 1944-1989. The "defining process" is under the strict guidance of concepts, such as peace and conflict, formulated by Professor Johan Galtung. Any individual, community or nation can be analysed under these Galtung's concepts in order to correctly determine and define if there is really existing peace (which could be negative and positive) or there is pure conflict (even war) by preventing basic human needs. In the light of these concepts, this study is investigating the Turkish minority in the relevant period in order to determine and define the conflict and/or peace situations that this community faced.

Method: This article is based on empirical fact, such as it is analysing archival documents and secondary sources produced by these archives. The main focus is to analyze the facts and to avoid any biased interpretations. Having this in mind, the inductive and deductive techniques are used to have generalized view to the problem.

Findings: In brief, in the light of Galtung's concepts, the article finds that the Turkish minority experienced violence (all types of violence described by Galtung), and also it has lived either in positive peace conditions nor in negative peace, or in other hands the Turkish minority during the BCP rule (1944-1989) didn't reach its potential and has lived under apparent conflict: direct, structural and cultural violence.

Conclusions: As a result, it has been seen that during the Cold War period, structural violence has been explicitly and clearly applied, including direct violence against the Turkish minority. Consequently, hundreds of thousands Turks fled from oppression and took refuge in Turkey. In this period, it is very difficult to say that the Turks live in peace except some nebulous periods. Especially in the period of 1984-1985, when the names of Turks were changed, Bulgaria becomes most difficult place in the history of the Turkish minority. In this period, hundreds of Turks were deliberately killed as a result of pressure and torture. Not only the names of the Turkish minority were changed, but various pressures continued thereafter. It was forbidden to speak Turkish on the streets, cultural activities were not allowed, Turkish publications were forbidden, religious symbols were prohibited and religious responsibilities were not allowed to be fulfilled. In short, both personal / direct violence was experienced in this period and structural violence was the strongest and most obvious. In terms of Galtung's concepts, the need for security of the Turkish minority, the need for welfare, the need for identity and the need for freedom have been deliberately prevented and Turks' potential have been intercepted from reaching its full potential with the structural and direct violence. The term of Reviving Process ("Vazroditelen Protses") was apparent propaganda aiming to convince the Turkish minority that they are actually Bulgarians that have been assimilated by Ottomans and now the state is helping these citizens to find their real Bulgarian roots. According to the Galtung's model, this act of logical reasoning of the fault deed can be determined as a cultural violence. As a result, neither the negative peace nor the positive peace has been experienced by Turkish minority during the Bulgarian Communist Party (BCP) rule. 


\section{GIRİŞ}

İnsan olarak tanımlanan varlığın doğasına en uygun olan ve de arzu ettiği yaşam biçimi her türlü şiddetten uzak olarak barış ve sükûnet içinde yaşamını devam ettirmesidir. Ancak bu ideal reel dünyada çoğunlukla çeşitli engellerle karşılaşmaktadır. Bazen engeller hemcinsinin fiziksel müdahalesinden gelmekte bazen de kendisinin kurduğu yapıların etkisiyle barış ve sükûnet içinde yaşama potansiyelini gerçekleştirememektedir. Barışa engel olan şiddet ve çatışma tüm boyutlarıyla doğru bir şekilde anlaşılması gerçek barışın hak ettiği değeri görmesi açısından vazgeçilmez bir şart olmaktadır. Prof. Johan Galtung şiddet ve çatışma sorunsalını detaylarıyla ortaya koyup çatışmaları çözmek ve barışı tesis etmek üzere kapsamlı araştırmalar yapmış önemli bir akademisyendir. Bu çalışma da Johan Galtun'un çatışma çözümleri ve barışı tesis etme anlayışından şiddet ve barış kavramlarına değinerek Bulgaristan Komünist Partisi (BKP) döneminde (1944-1989) Bulgaristan'da Türk azınlığın maruz kaldığı durumu - şiddet veya barışı - analiz etmektedir. Araştırmanın amacı ilgili dönemde Türk azınlığın muhatap olduğu durumları resmi arşiv belgeleri 1şı̆̆ında tespit etmektir. Diğer taraftan bu çalışma yine arşiv belgeleri 1şı̆̆ında uygulanan şiddetin psikolojik motivasyonunu da ortaya çıkartmak yönünde bir başka amaca daha sahiptir. Devlet eliyle gelen baskı, şiddet veya barış hallerinin psikolojik motivasyonu yani olayların politik psikolojisi de şiddet ve çatışma durumlarına sebep olabilmektedir.

Şiddet ve çatışma durumlarının müsebbibi olabilecek güçte olan psikolojik motivasyonun iyi anlaşılması özellikle şiddet ve çatışmadan sonra istikrarlı barışın tesisinde üzerinde dikkatle düşünülmesi gereken son derece önemli bir nokta olmaktadır. Bulgaristan'daki Türk azınlığın durumu analiz edilirken bir taraftan tüm boyutlarıyla şiddet ve çatışma durumları tespit edilmesi diğer taraftan bunların müsebbibi olabilecek psikolojik temellerin çözümlenmesi sağlanıp uzun vadede tesis edilecek barışın istikrarlı olması için gerekli şartlar araştırılmaktadır.

Galtung'un geliştirdiği model daha çok tüm şiddet durumlarının (doğrudan ve yapısal) belirlenmesine yardımcı olmaktadır böylece barışın tesisinde hangi şiddet durumlarından kaçınılması gerektiğini göstermektedir. $\mathrm{Bu}$ modelin işlevselliği son derece önemli olmakla birlikte gerçek hayatta son derece kırılgan bir temel üzerinde bulunmaktadır. Uluslar arasındaki etkileşim tarihini konu edinen Siyasi Tarih milletler arasında barış hallerinin ne kadar çabuk bozulabileceğinin örnekleriyle doludur. Peki, bu kırılgan barış halinden daha istikrarlı ve sağlam temelli bir barış durumuna geçmek mümkün müdür? İşte bu makale, bu sorunsaldan hareket ederek bu soruya da politik psikoloji bağlamında cevaplar aramaktadır.

Her insan kendi potansiyelini tam olarak yaşamak ister. Bu ise hayati öneme sahip çeşitli ihtiyaçların karşılanması ile mümkün olabilir. Bunların arasına her türlü fiziksel, manevi, sosyal ve çevresel ihtiyaçlar girmektedir. Galtung, bu ihtiyaçların farklı sosyal zamanlarda ve farklı sosyal çevrelerde her insan için farklı önem dereceleri olabileceğini söylemektedir. Örnek olarak köle olarak doğmuş bir insanın en önemli sosyal ihtiyacı özgür olmaktır. Ancak çoğunlukla insanın farkında olmadığı ihtiyaç ile istekler arasındaki farktır. İhtiyaçlar insanın potansiyelini gerçekleştirmesi için gerekli şeylerdir. Şu da çok iyi bilinir ki, insanların bir şeyleri istemesi her zaman gerçekten potansiyelini gerçekleştirmesi için ona lazım olan bir şey olmayabilir. Dolayısıyla ihtiyaç insanoğlunun tam potansiyelini gerçekleştirmesi için gerçekten ve mutlak elzem olan bir gerekliliktir. Bu bağlamda Galtung'a göre ihtiyaç ile gereklilik arasında organik bir bağ söz konusudur. Bu gereklilikler farklı sosyal zaman ve mekânlarda farklı olmaktadır. Galtung’a göre insanlık için üniversal bir ihtiyaç listesi oluşturmak mümkün değildir. Ama belli başlı sınıflandırmalar yaparak genel anlamda her insanın sosyal çevresine ve sosyal zamanına göre ihtiyaçlar belirlenebilir. Galtung modelinde dört temel ihtiyaç şunlardır: çatışmayı önlemek için "güvenlik ihtiyacı", safahattan kaçınma için "refah ihtiyacı", yabancılaşmamak için "kimlik ihtiyacı" ve baskıdan kurtulmak için "özgürlük ihtiyacı". Bu temel gereklilikler insan potansiyelinin gerçekleşmesinde elzem olan unsurlardır. Galtung’a göre ihtiyaçların karşılanması tesadüfî bir olgu değildir. Tabiri caiz ise ihtiyaçların karşılanması gökten zembil ile düşmemektedir. $\mathrm{Bu}$ ihtiyaçların tatmin işlevi ya insanlar tarafindan ya da insanların kurguladığı yapılar tarafından olmaktadır. Bu bağlamda yukarıda özetlenen dört temel ihtiyaç iki şekilde tatmin edilebilir ya insanlar (aktörler) ya da sosyal yapı tarafından. Bu tipolojik ayrımdan sonra Galtung modelinde ihtiyaçların engellenme durumlarına da değinmek gerekir. Bu engelleme yine ya aktörler tarafından ya da süjesi belli olmayan yapılar tarafindan olabilir (Healey, 1979: 10). 
Yukarıda özetlenmeye çalışılan ihtiyaçlar dikkate alındığında insanoğlunun barış ve sükûnet içinde yaşaması bu unsurların sağlanmasına bağlıdır denilebilir. Ancak Galtung'un barış ve şiddet modeli bağlamında bakıldığında geçmişten günümüze dünya tarihinde bu ihtiyaçların kişiler veya yapılar tarafindan bir şekilde engellendiği görülmektedir. İnsanlık tarihinde siyasi bir organizasyonu temsil eden devletler var olduğundan beri şiddet, savaş ve yıkımların varlı̆g 1 hep söz konusu olmuştur. Diğer taraftan yine siyasi tarihte barış olarak tanımlanan olgu dahi çoğu zaman bir şekilde şiddeti içinde barındırmış ve tam anlamıla gerçek barış oluşamamıştır.

Osmanlı devleti 1396 yılında İkinci Bulgar Krallığı'na son vermesi ile Bulgaristan topraklarına iskân politikaları ile Anadolu'dan gelen Osmanlı Türkleri yerleştirilmiştir. Zamanla Türk nüfus Bulgarlar arasında ciddi bir seviyeye ulaşabilmiştir. İkinci Bulgar Krallığı'nın yıkıldığ 1 tarihten Bulgaristan'ın tekrar tam bağımsızlığını kazandığı 1908 yılına kadar geçen yaklaşık 500 yıllık zaman dilimi Bulgar ulusunca "Türk Esaret Yılları" olarak bilinir. Bu zaman diliminin ortalarına denk gelen, XVIII. yüzyılın ikinci yarısında Bulgarlar arasında bağımsızlık için bir uyanış ve ulusal bağımsızlı̆̆ını tekrardan kazanma gayretleri oluşmuştur. Bu dönem Bulgar Dirilişi ("BılgarskoVızrajdane") olarak bilinir ve genellikle tüm eylemsel aktivite Bulgar egemenliğini zorla almış Türkler etrafında dönmektedir. Bu dönemin en belirgin özelliği yönetici Türklere karşı her cephede mümkün olan her türlü araçla mücadele vererek tekrar kendi devletini geri kazanmaktır. Bu olgusal amaç hem Bulgar tarihinde hem de Bulgarların ulusal bilincinde çok derin psikolojik imgelere sahip bir süreçtir. Bulgar ulusal bilincinde "Türk Esaret Yılları" olarak bilinen dönem bütün yazılı ve sözel, siyasi, kültürel ve sosyal çalışmalarda "kötü” ve "zorba" olan Türk nesnesini tasvir etmektedir. Bundan dolayı Bulgar kimliğinde ve daha sonra Bulgaristan devletinin kurucu temellerinde Türk imgesi iyi çağrışımlara sahip değildir (Dimitrov, 2006).

Bulgar devleti ve milletinin bu yapısal özellikleri dikkate alındığında, Bulgaristan'ın 1908 yılında tam bağımsız olması ile birlikte ülke içinde kalan Türkler kendini güvensiz hissetmeye başlamış ve ana vatana ricat başlamıştır. Bu tarihten sonra Soğuk Savaş'ın bitimine kadar önce Osmanlı Devleti'ne ve daha sonra da Türkiye Cumhuriyeti'ne çok fazla Türk göçleri olmuştur. Göç rakamları geri dönenler de olduğu için tam tespit edilemese de yaklaşı bir milyon civarında olduğu tahmin edilmektedir. Bazen bu göçler Türklerin kendi talebi üzerine olmuş bazen de mecburiyetten ve şartların zorlaması ile olmuştur. Bazen de göçler karşılıklı olarak Bulgar ve Türk devletlerinin anlaşması sonucunda gerçekleşmiştir. İlginç olan da bazen bu göçler Bulgar veya Türk hükümetleri tarafından engellenmiştir. Sonuç itibariyle yüz binlerce Türk ve Müslüman Türkiye'ye göç etmiş ancak yine de Bulgaristan'da azımsanmayacak oranda ciddi bir Türk nüfusu kalmıştır. Günümüzde Türkler azınlık konumundadırlar ve sayıları toplam Bulgar nüfusuna oranla \%8-9 civarındadır. Bu da günümüz şartlarında yaklaşık 500-600 bin civarına denk gelmektedir (Jelyazkova, 1998).

Anlaşılabileceği gibi Bulgaristan'daki Türklerin tarihi çok eskilere dayanmaktadır. Ancak çok önemli bir nokta şudur ki, günümüz Bulgar kimliğinin büyük bir kesimi olumsuz imgeler içeren Türk nesnesi üzerine inşa edilmiş olmasıdır. Bu da doğal olarak Bulgar devletinin tekrar kurulmasından sonra benzer acıların karşı tarafa da yaşatılması veya psikolojik bir ihtiyaç olarak en azından Türk azınlığın normal bir düzen içinde hayatlarını devam ettirmeleri birçok şekilde engellenmiştir. Diğer bir deyişle, Galtung modeli bağlamında düşünüldüğünde Türk azınlığı çok fazla şiddet durumlarına maruz kalmıştır denilebilir. Bu durum özellikle de Sovyet Ordusu'nun yardımıyla 1944 yılında komünist partinin iktidarı ele geçirmesi ile demokratik ve insan onuruna saygılı dönemin kapanması ve otoriter bir düzenin yerleşmesiyle daha da belirgin olmuştur. İşte bu çalışmanın da amacı Galtung'un barış ve şiddet anlayışını ampirik bir örnek ile ele alarak Bulgaristan'daki Türk azınlığının uğradığg şiddet durumlarını tespit etmektir.

\section{JOHAN GALTUNG'UN BARIŞ MODELI}

Johan Galtung modeli her şeyden önce bir barış modelidir. Bir başka deyişle insanlığın barışa ulaşması için kurtulması gereken şiddet durumlarının neler olduğunu irdeler. Bu şiddet durumlarının iyi anlaşılması ve ortadan kaldırılması ile insanoğlunun bedensel ve zihinsel potansiyelini yaşayacağı üzerine sistemleştirilmiş bir çalışmadır. 
Galtung, teorik açıklamalarına başlarken barış ve şiddetin birbiriyle ilişkili iki kavram olduğunu söyleyerek en klasik anlamda barışı şiddetin olmadığı bir durum olarak tanımlamaktadır. Barış ve sükûnet insanlığın özlemidir. Ancak çoğu kez şiddet ile engellenmektedir diyerek barışa ulaşmanın tek yolu şiddeti ortadan kaldırmaktır açıklamasını yaparak şiddet kavramı üzerine düşünmektedir. İnsanoğlunun bir şekilde ulaştı̆g mevcut bedensel ve zihinsel gelişimi, potansiyel gelişimi altında kalması durumunda orada şiddet vardır, bu şiddet yüzünden tam potansiyeline ulaşamamıştır diyerek kavramın fonksiyonel özelliğini ortaya koymaktadır. Böylece kavramı sınırlandırma hakkında yaptı̆̆ ilk açıklamalarda şiddeti, "potansiyel ile şu an mevcut olan duruma engel olan şey" olarak tanımlamaktadır. Tanımı biraz daha açarsak insan potansiyelinin bedensel ve zihinsel olarak ulaşabileceği durumlara ulaşmayı engelleyen ve böylece insanın kendi potansiyelinin altında kalmasına neden olan her türlü engelleme kısaca şiddet olarak tanımlanmaktadır (Galtung, 1969: 168).

\section{1. Şiddet Türleri: Kişisel (Doğrudan), Yapısal ve Kültürel}

Galtung, şiddet olgusunu sınıflandırmada birkaç yol göstermektedir. Teorik tipolojisinde şiddeti üç türe ayırır: kişisel veya direk/doğrudan; yapısal veya dolaylı; son olarak da kültürel veya sembolik şiddet. Şiddeti uygulayan bir aktörün (belirlenebilen bir kişinin) olduğu durumlarda kişisel veya doğrudan bir şiddetin olduğunu söylemektedir. Şiddeti uygulayan bir kişinin veya aktörün bulunamadığı durumlarda ise uygulanan şiddetin yapısal veya dolaylı şiddet olduğunu belirtmektedir. Her iki şekilde de şiddete maruz kalan insanların öldürülebileceğini veya sakat bırakılabileceğini, bedensel ve/veya zihinsel vurulup incitilebileceğini veya aldatma yöntemiyle manipüle edilebileceğini bildirmektedir. Kısaca sonuçlar aynı olabildiği halde bunlara sebep olan süjenin takip edilip edilemediğine göre bir ayrışma söz konusu olmaktadır. Kişisel/direk şiddet durumunda şiddeti yapan bir kişi/aktör söz konusudur. Yapısal şiddet durumunda ise şiddeti oluşturan kişinin ortaya çıkartılması anlamsız olmaktadır, böyle bir kişi yoktur. Bu noktada bir kişinin doğrudan bir başka kişiye zarar vermesi söz konusu değildir, kişiye zarar veren yapı içinde inşa edilmiş şiddettir (örnek olarak eşit maddi güce sahip olmama durumunun doğal sonucu eşit olmayan hayat firsatları doğurmaktadır) (Galtung, 1969: 170-171).

Daha sonraki çalışmalarında şiddetin üçüncü kategorisi de tanımlamaktadır. Kültürel şiddet, direk veya yapısal şiddeti haklı çıkarmak veya meşrulaştırmak için kullanılan kendi varlığımızın sembolik ve kültürel yönleri olarak tanımlanmaktadır. Burada insanlığın sahip olduğu tüm kültürel yönlerin kültürel şiddet olarak algılanması çok doğru bir kavrayış değildir. Daha çok tercih edilen çok özel kültürel bir görünümün bazı yönleri direk veya yapısal şiddet durumlarını doğru bir şeymiş gibi gösteriyor veya doğru bir şeymiş gibi hissettiriyorsa işte bu kültürel şiddettir tanımı yapılmaktadır. Kültürel şiddetin çalışma prensibinde belli bir tutumun moral rengini kırmızıdan/yanlıştan yeşile/doğruya veya en azından sarıya/kabul edilebilire çevirme olduğu vurgulanmaktadır. Bir başka deyişle, kültürel etkiyle, gerçekte yanlış olan bir durumu doğru algılatan kültürel değerler kültürel şiddettir. Örnek olarak "devletin bekası için adam öldürmek doğrudur ama insan için birini öldürmek yanlıştır ” bakış açısı kültürel bir şiddettir (Galtung, 1990: 291-292).

Yukarıda özetlenmeye çalışılan üç çeşit şiddetten en açık ve bariz olanı kişisel/doğrudan şiddettir. Bu kategori içine tehditten psikolojik saldırıya, tecavüzden öldürmeye, savaştan soykırıma kadar her kategori şiddet türü girmektedir. Bu şiddet çeşidinin en belirgin özelliği kişisel/doğrudan şiddet olarak bilinmesidir zira şiddetin failleri insanlardır. İkinci tür şiddet yani yapısal şiddet daha az belirgindir ama sonuçları itibariyle aynı şekilde zararlı hatta uzun vadede kişisel şiddetten daha da zararlı olabilir. Genelde belirli bir kişi veya kişiler şiddetin sorumlusu olarak bulunamaz. Burada şiddet, insanların oluşturduğu sosyal, politik ve ekonomik yapıların bizatihi yapısal parçası olmuş durumdadır. Bu tür bir şiddetin görülmesi oldukça zordur nitekim insanın hayatını devam ettirdiği dünyada düzenin kendi doğrularını oluşturması ile şiddet normal ve doğal bir şey olabilmektedir. Galtung, kişisel ve yapısal şiddeti tespit etmedeki farklılığı şu şekilde açıklamaktadır. Kişisel şiddette açık bir şekilde süje ve obje ilişkisi vardır. Yapısal şiddette ise bunu açıkça tespit etmek mümkün değildir diyerek bir toplumda bir erkek eşini dövüyorsa kişisel şiddet olduğunu ancak yine aynı toplumda bir milyon erkek eşlerini göz ardı edip ikinci kategori insan olarak görüyorsa burada yapısal şiddetin olduğunu söylemektedir (Galtung, 1969: 171). 
Kültürel şiddete gelince, şiddet doğrudan veya yapısal olsun sonuç itibariyle insanın meydana getirdiği bir olgudur. Şiddet bir taraftan insanların var olma durumunu tehdit ederken diğer taraftan da şiddetin meşrulaştııılması veya yasallaştırılması sorunsalı vardır. Her iki tür şiddet bir şekilde meşrulaştırılma ihtiyacı duymaktadır. $\mathrm{Bu}$ meşrulaştırma ise inançların, tutumların ve sembollerin dünyasında olmaktadır. Sonuç itibariyle doğrudan veya yapısal şiddet bir şekilde kültürden beslenmektedir, kültür tarafından meşrulaştırılmaktadır. Şiddetin kültürel öğelerle meşrulaştırılması çoğunlukla dinden, ideolojiden, dilin yapısal özelliğinden, sanattan, ampirik bilimden, formel bilimden ve evrenbilimden beslenerek olmaktadır. Bir toplumun dini yapısı ve buna dayalı olarak gelişen kültürel değerleri doğrudan ve yapısal şiddete sebep olabilir. Örnek olarak Galtung, İsrail'in politikalarını göstermektedir. İsrail halkının seçilmişliği ve kendilerine verilmiş vaat edilmiş toprakları Eretz Yisrael ile kültürel kodlama yapılmıştır. Filistinlilere karşı bu kültürün kodlamanın meşrulaştırması ile her türlü şiddet meşru görülmektedir. Bunlar arasında öldürme, sakatlama, maddi imkânlardan yoksun bırakma, İsrail devleti içinde Yahudi olmayanlara karşı sosyal dışlama ve ikinci sınıf vatandaş muamelesi, tutuklama, bireysel veya toplu sınır dış1 etme tehdidi gibi her türlü şiddet meşrulaşabilmektedir. Yine yukarıda belirtildiği gibi doğrudan veya yapısal şiddete sebep olan ideoloji de bir toplumun kültürel değerlerini şekillendirerek kültürel şiddetin kodlanmasında etkili olabilir. Örnek olarak bir zamanlar Avrupa’yı kasıp kavuran milliyetçilik, sosyalist ideoloji (Sovyetler Birliği) ve nasyonal sosyalist (Nazi Almanya's1) bu kapsamda değerlendirilebilir (Galtung, 1990: 296-301).

Kültürel şiddet öylesine sessiz bir şekilde ortalıkta dolaşmaktadır ki, Galtung normal şartlarda insanın bu şiddetin varlığından haberdar olması gerçekten çok zordur demektedir. Misal olarak dilin yapısından kaynaklı kültürel şiddet birçok toplumda doğrudan ve yapısal şiddeti meşrulaştırmaktadır. Örnek olarak Alman ve Norveç dillerinin gramer yapısında kadın için ayrı bir kelime yoktur (ama örnek olarak İngilizcede vardır). Sadece erkek cinsiyetini belirten kelime söz konusudur. Ve bu kelime hem erkeği hem de kadını tanımlar. Böylesi bir toplumun yazılarında ve hatta konuşmada kadın cinsiyeti kaybolur, erkeğin egemen olduğu bir anlatım söz konusu olur. Bu durum daha sonra toplumda çeşitli yapısal şiddet olaylarını farkına varmadan meşrulaştırır. Bir diğer örnek bilimin dahi kültürel şiddet üretebileceğidir. Bu bağlamda neo-klasik ekonomi doktrinini geliştiren Adam Smith geleneği örnek verilebilir. Bu yaklaşımda uluslararası ticaret göreceli avantajlı pozisyonlara sahip uluslar arasında iş bölümüne göre belirlenir. Buna göre hammadde zengini ve vasıfsız insan gücüne sahip ülkelerin görevi hammadde temin etmektir. Yüksek teknolojiye, sermaye ve eğitimli insan gücüne sahip ülkelerin görevi ise bu hammaddeleri işlemek ve ticaret yaparak diğer ülkeleri de kalkındırmaktır. Ancak Galtung'a göre bu ekonomik yaklaşım teknolojik ve sermaye sahibi ülkelerin daha da gelişip zenginleşmesine, hammadde ihraç eden ülkeleri ise işçi ülkelerine dönüştürmektedir. Böylece dünya çapında yapısal bir şiddet oluşmaktadır (Galtung, 1990: 300).

\section{2. Şiddetin Yokluğu: Negatif ve Pozitif Barış Kavramları}

Savaş ve çatışma insanlık tarihi kadar eski bir kavramdır. Geçmişten günümüze insanlık doğrudan veya dolaylı olarak savaşa bir şekilde maruz kalmıştır. Ancak tarihi kayıtlar göstermektedir ki hiç bir insan savaş halinde yaşamaya razı olmayıp hep barış ve sükûnete ulaşmaya çalışmıştır. En klasik anlamda savaş ve çatışmanın olmadığı durumları yani barışı yaşamak her insanın tabii isteği olmuştur. Galtung ise barış hakkındaki bu genel tanımın ötesine geçerek kavram hakkında çok farklı bir anlayış ortaya koymuştur. Bu anlayış barışın kapsamını ve anlamının derinliğini ortaya koymaktadır. Tıpkı şiddet konusunda olduğu gibi barışın da farklı türlerini açıklamıştır. Bu yaklaşıma göre barışın iki boyutu vardır. Birinci boyutunda kişisel veya doğrudan şiddet yoktur. Ancak yapısal şiddet devam ettiğini düşünülürse bu durum "negatif barış" olarak tanımlanmaktadır. Barışın ikinci boyutu ise hem kişisel/doğrudan şiddetin yokluğu hem de yapısal şiddetin olmaması durumunda "pozitif barış" vücut bulmaktadır. Diğer taraftan Galtung, pozitif barışın aynı zamanda sosyal adalet demek olduğunu da dile getirmektedir. Yapısal şiddetin yokluğunda doğal kaynaklar ve maddi gücün insanlar arasında adaletle dağıtılması söz konusu olur. Bu ise insanlığın gelişmesi yani bedensel ve zihinsel potansiyelini yaşaması anlamına gelmektedir. Galtung, barış konusunda yapılan araştırmaların insanlığın geçmişinde, şimdiki anında ve gelecekte tam anlamıyla barışı gerçekleştirip gerçekleştiremediği ile ilgili olduğunu söyler. Barış durumunun tam olarak ortaya çıkarılması için çatışma ve gelişme hakkında araştırmaların da yapılması gerektiğini söyler. Nitekim çatışmalar hakkında yapılacak araştırmalar neticesinde negatif barışın oluştuğu durumlar ortaya çıkartılabilecektir. Aynı şekilde gelişme 
hakkında yapılan araştırmalar ile de pozitif barışın olduğu zamanlar tespit edilebilecektir. Bir başka deyişle çatışma araştırmaları ile negatif barış arasında ve gelişmişlik araştırmaları ile pozitif barış arasında anlamsal bir bağın olduğunu söylemektedir (Galtung, 1969: 183).

Bu kavramsal ayrışma sonrasında Galtung, tam anlamıyla hem negatif hem de pozitif barışın beraber olduğu gerçek barış hali insanlık tarafından yaşanabilir mi diye bir sorgulama içine girmektedir. İnsanlık tarihine bakıldığında neredeyse birinin veya her ikisinin de tam oluştuğu bir zaman dilimi geçmemiştir. Bu bağlamda gerçek anlamda doğrudan ve yapısal şiddetin olmadığı ve böylece tam anlamıyla barışın hâkim olduğu bir zaman dilimi bulmak gerçekten zordur. Ancak yine de Galtung, bunun hayalî bir amaç olarak algılanmaması gerektiğini söylemektedir. Bazı insanlar için doğrudan şiddetin olmaması ama yapısal şiddetin olması tercih edilebilir. Bunun tersi durumlar da olabilir. Böyle bir önemlilik sıralaması yapılmaktadır. Ancak Galtung'un görüşünde hangi şiddet olursa olsun bir şekilde barışa engel oluyorsa sonuç değişmediğinden birini diğerine tercih etmemek gerekmektedir. Hiçbir zaman kişisel şiddetin yok olduğu ve sosyal adaletin var olacağı bir ortam oluşmaz söylemlerini aşırı derecede kötümser bulmakta ve böyle düşünenleri zihinsel ve ahlaki olarak teslim olmakla eleştirmektedir. Buradan yola çıkarak barış araştırmalarının gayesi gerçeklikten uzak ve hayalî olmadığını, her iki hedefin (negatif ve pozitif barış) de önemli olduğu ve insanlık için gerçek anlamda barışın ulaşılabilir olduğunu düşünmektedir (Galtung, 1969: 185-186).

Her ne kadar imkânsız gibi görünse de barışın ulaşılması mümkündür. Amaç depolarizasyondur, bir başka deyişle hedef düalist durumdan kaçınmaktır. En önemli sorun zihinsel ve davranışsal düalizmin ortadan kalkmasıdır. Zihinsel düalizmde insan iç dünyasında iyi ve kötüyü ayırır, her iyi şey kendisiyle ilişiktir her kötü şey ise diğerine aittir. Bu zihinsel kurgulama doğal olarak davranışlara ve oradan da dünya düzenine yansımaktadır. Böylece dış dünyada kutuplar oluşmakta, bir tarafta her şeyin iyisiyle ilişkilendirilen bir kutup diğer tarafta ise her şeyin kötüsüyle ilişkilendirilen bir kutup oluşmaktadır. Bazen de hiçbir şey ile ilişkilendirilmeyen kutuplar vardır. Sonuç itibariyle zihinsel polarizasyon davranışsal kutuplaşmayı teşvik eder. Böylece şiddeti meşrulaştıran kültür gelişir. Galtung'un düşüncesinde bu depolarizasyon veya hümanizasyon ile önlenebilir. Bu ise öncelikle zihinlerde ben ve öteki için daha normal görüşlere sahip olmakla başlar. Bunun en pratik yolu insanın kendi içindeki polarizasyonu zihinsel/duygusal olarak reddetmesidir. Böylece barış inşa etme süreci başlar demektedir. Bu süreç bir kere başlayınca kişiyi sadece belli bir tutuma ulaştırmaz aynı zamanda yeni söylem ve yeni düşüncelere ulaştırır. En temel özellik kapalı olmayan açık bir zihin canlanır, bu ise risk alarak düşünmeyi, konuşmayı ve hatta o uğurda hareket etmeyi teşvik eder (Webel ve Galtung, 2007: 29).

\section{BULGARISTAN'DAKİ TÜRK AZINLIK VE ŞIDDDET}

Bulgaristan'daki Türklerin durumu 1990'lı yıllarda komünist rejimin sona ermesiyle birlikte ve de ülkenin Avrupa Birliği (AB) ve NATO gibi uluslar üstü/uluslararası örgütlere katılmasıyla kısmen düzelmiştir. Ama yine de Galtung modeli dikkate alındığında bazen kişisel ve çoğu zaman da yapısal şiddete maruz kalmaya devam etmektedirler. Türk azınlığa karşı gerek doğrudan gerekse yapısal şiddetin en şiddetli olduğu zamanlar ise İkinci Dünya Savaşı sonrası Bulgaristan Komünist Partisi'nin (BKP) iktidarı dönemine denk gelen Soğuk Savaş yılları olmuştur. Komünist rejimin yönetime hâkim olduğu o yıllarda sadece Türkler değil Bulgar halkı da çok fazla şiddete maruz kalmıştır. Ancak Türklerin devlet içerisindeki ikinci sınıf vatandaş olarak görülmeleri, tarihten gelen psikolojik motivasyonlar ve de azınlık statüleri (az sayıda olmaları) nedeniyle daha fazla şiddete maruz kalmışlardır. Bu başlık altında İkinci Dünya Savaşı sonrasından Bulgaristan Komünist Partisi'nin (BKP) 1989 yılında iktidarını kaybettiği zamana kadar Türklerin uğradığı şiddet durumları incelenecektir.

\subsection{Bulgaristan'da Soğuk Savaş Yıllarında Türklerin Durumu}

Yukarıda kısmen özetlenmeye çalışıldığı gibi İkinci Bulgar Krallığı egemenliğini 1396 yılında kaybedince Bulgar halkı kendi ülkelerinde siyasi haklardan yoksun kalmıştır. Bu tarihten 1878 yılında kadar Osmanlı Devleti içinde çeşitli organizasyonlar kurarak siyasi bağımsızlığını elde etmeye çalışmışlardır. Bu dönemde Bulgar ulusal kimliğinde düşman ve öteki imgesi hep Türkler olmuştur. Bulgar ulusal kimliğinde 
Türk imgesi genellikle kötü tabirlerle anılmakta ve tarihi ulusal yazılarda öyle bilinmektedir. Ulusal bilinçte Türk, Bulgar ailelerinin küçük erkek çocuklarını zorla alıp yeniçeri yapan ve onları Türkleştiren bir "zorbadır"; canının çektiğini gasp eden, güzel tarlaları ve evleri alan, güzel kiliseleri camiye çeviren, karşı koyanları ise sorumluluk yüklenmeden öldüren "hırsız", "açgözlü" ve "katil" nesne imgesi hep Türkler olmuştur (Gradeva, 2001: 113-134).

Günümüzde dahi çok güçlü bir şekilde etkisi hâlâ devam eden İstoriya Slavyanobılgarska (Slav-Bulgar Tarihi) adlı tarih kitabında mitleştirilen ve yoğun politik duygu yüklenen ünlü "Türk esareti altında" söylemi (Hilendarski, 2004: 36) Türklere yönelik ulusal psikolojinin temelleri olduğu söylenebilir. Bu ifade daha sonra milli yazar İvan Vazov'un en önemli milli roman eserine de ("Pod Igoto" - Esaret Altında) başlık olmuştur ve Bulgar bilincinde çok güçlü bir kölelik/esaret imgesi yarattığı gibi sonraki yıllarda politik sonuçları olabilecek bir mağduriyet duygusu da şekillendirmiştir

Ulusal bilince Türk algısı olumsuz imgeler ve kötü hatıralar ile yerleştiğinden dolayı Berlin Antlaşması (1878) ile Bulgar Prensliği kurulduktan sonra Bulgar yöneticiler istenmeyen bu kişilerden kurtulmak için çok uğraşmışlardır. Bu bağlamda ilk Bulgar kralı olan Ferdinand daha sonra Kral III. Boris gibi yöneticiler Bulgar halkı içinde Müslüman - Türk azınlıktan nasıl kurtulabiliriz sorusuna en pratik şekilde cevap bulmaya çalışmışlardır. Çözüm genellikle Osmanlı Devleti ve daha sonra da Türkiye Cumhuriyeti’yle yapılan ikili anlaşmalarla şekillenen göç politikaları ile bulunmaya çalışılmıştır. Bu uygulamalar genelde insan haklarına saygılı ve uluslararası hukuka uygun bir şekilde görülmüştür. Ancak İkinci Dünya Savaşı sonrasında, 1944 yılında, Bulgaristan Komünist Partisi'nin (BKP) Sovyet Ordusu'nun doğrudan yardımıyla iktidara gelmesiyle birlikte Todor Jivkov yönetiminde uygulanan tedbirler çok daha uç noktalara varmıştır. Örnek olarak 1960 yılında Milli İstihbarat Plovdiv Ofisi dokümanları arasında bulunan resmi bir belgede son derece ciddi ifadeler yer almaktadır. Bulgaristan Komünist Partisi'nin (BKP) Merkezi Yönetim Kurulu (MYK) için hazırlanan bir raporda Türk azınlığın hiçbir şekilde eğitim almaması ve fazla geçim kaynağ olmayan yerlerde yaşamını devam ettirmesi gerektiği bildirilmektedir. İlgili rapor şu ifadelerle bitmektedir (Chakarov $\left.{ }^{1}, 2001\right)$ :

“..öyle çalı̧̧malıyı ki bu toplumun sadece imamları okuma yazma bilmeli, eğer bunu değiştirir okuma yazma ögretirsek, kültürlerini geliştirmelerine izin verirsek bu durum değişir ve o zaman imamları kontrol edemeyiz böylece Bulgar devleti de eritilip entegre edilemeyen bu halkı kontrol edemez.."

$\mathrm{Bu}$ ve buna benzer raporlar ile daha sonraki yıllarda komünist partinin Türk ve diğer azınlıklara yönelik uygulayacağı programlar şekillenmiştir. Diğer taraftan zaten Bulgar Komünist Partisi Merkezi Yönetim Kurulu'nun daha 1949 yılında Stalin ile yaptığı bir görüşmenin sonradan açıklanan resmi bir belgesinde Türk azınlık için "güvenilir olmayan eleman" ("neblagonadejden element") tanımı yapılmış bundan dolayı da Bulgaristan'ın güney sınırları yakınlarında yaşamaları çok sakıncalı görülmüştür. Çözüm olarak ise devlet eliyle güney sınırda yaşayan Türkleri Bulgaristan'ın iç kesimlerine doğru göç ettirmek ve yerlerine de çeşitli imkân ve avantajlar tanıyarak Bulgarların göç etmesini sağlamak olmuştur (Ognyanov, 2008: 26).

Devlet gücü kullanılıp mecbur bırakılarak Bulgaristan'ın iç kesimlerine göç ettirilme ile yüz yüze kalan birçok Türk baskılara dayanamayıp Türkiye’ye sığınmıştır. Resmi verilere göre 1949-1952 yılları arasında Bulgar devletine güvenini yitiren 155 bin Türk kendi isteğiyle (ama buna mecbur birakılarak) ülkeyi terk etmiş ve Türkiye'ye sığınmıştır (Gruev ve Kalionski, 2008: 118-119).

Yukarıda verilen örnekler Galtung modeli bağlamında incelenirse çok açık bir şekilde karşıya şiddetin farklı boyutları çıkmaktadır. Devlet imkânları kullanılarak bilinçli bir şekilde ülkenin eğitim sistemi ve bu sisteme erişme mekanizmaları kapalı kapılar arkasında temel hakları ihlâl edecek şekilde tasarlanmış olduğu anlaşılmaktadır. Bilinçli bir şekilde Türk azınlığın eğitim alması engellenmeye çalışılmıştır. Benzer şekilde bir de Türklerin ülkenin en zor koşullarına sahip, iş imkânlarının çok az olduğu, kıt kanaat geçimin ancak mümkün olabileceği bölgelerde yaşamlarını sürdürmelerine izin verilmesi söz konusu olmuştur. Eğitim ve

${ }^{1}$ Kostadin Chakarov, Bulgaristan Halk Cumhuriyeti devlet başkanı ve Bulgaristan Komünist Partisi (BKP) genel sekreteri Todor Jivkov'un ve kızı Lyudmila Jivkova'nın baş danışmanlığı yürütmüş, birincil kaynaktan bilgiler paylaşabilen bir kişidir. 
meslek sahibi olma hakkı insanın vazgeçilmez öneme sahip hakları arasındadır. Bilerek ve isteyerek bunun engellenmesi veya çeşitli vesilelerle eğitime eşit şartlarda ulaşmanın zorlaştırılması insan haklarının bariz bir şekilde çiğnenmesi anlamına gelmektedir. Yukarıda aktarılmaya çalışılan Galtung'un teorik yaklaşımında insanoğlunun dört temel ihtiyacından biri olan özgürlük ihtiyacı yani seçme özgürlüğü bu uygulamalarla Türklerin elinden alınmıştır. Bu dönemde Türk azınlığın yaşadığı yeri seçme imkânı elinden alınmış ve istemedikleri halde devlet eliyle ülke içlerine iskân ettirilerek göçmen olmuşlar, oradaki yerel halk için ise yabancı konumuna düşürülerek Galtung modeline göre ellerinden kimlik ihtiyacı da alınmıştır. Benzer şekilde mesleğini seçme imkânı da yasaklanmıştır. Kalifiye eğitimden uzak tutularak en aşağı seviyede, ağır ve zahmetli işleri yapmaya mecbur bırakılmışlardır. Böylece mesleğini özgürce seçebilme (özgürlük ihtiyacı) imkânı da ellerinden alınmıştır. Bu durumun doğal sonucu olarak yine Galtung modelinde tanımlanan refah ihtiyacından da yoksun bırakılmışlardır böylece sadece yaşamlarını devam ettirebilecekleri bir sefalet içinde sıkışıp kalmışlardır. Mesela en seçkin ve zeki olan Türkler ancak lise seviyesine kadar eğitim almalarına müsaade edilip bunun ötesinde bir eğitim almak isteyenler ise Devlet Güvenlik Ajansı (istihbarat) tarafindan çok sıkı bir takibe alınması ve acımasızca engellenmesi üzerine kurgulanmış bir politika söz konusu olmuştur (Jelyazkova, 1998).

Türkler, potansiyellerinin altındaki iş kollarında çalışmaya mecbur bırakılarak refah seviyeleri normal şartlarda ulaşabilecekleri seviyenin çok altına düşmüştür. Bütün bu sonuçlar değerlendirildiğinde yapısal bir şiddetin oluşmuş olduğu gözlemlenebilmektedir. Normal şartlarda ulaşabilecekleri potansiyel durumdan sistematik bir engelleme ile oldukça altına inmek zorunda bırakılmışlardır. Galtung modeli bağlamında bu şiddet durumu değerlendirildiğinde, bu şiddeti uygulayan doğrudan sorumlu tutulabilecek bir kişi veya kişiler yoktur. Söz konusu olan Bulgaristan Komünist Partisi’nin (BKP) yayımladığı gizli bir genelge ile tüm ülke çapında sistemik bir baskı uygulanmasıdır. Dolayısıyla faili açıkça belli olmayan ya da tam olarak belirlenemeyen bir şiddet durumu oluşmuştur. $\mathrm{Bu}$ sistematik engelleme durumu yapısal şiddet olarak tanımlanabilir. Galtung'un yaklaşımına göre barış konusu değerlendirildiğinde sadece negatif barış oluşmuştur denilebilir. Pozitif barış anlamında yapısal şiddetin de ortadan katlığı bir durum oluşmamıştır.

Bulgar Komünist Partisi (BKP), 1949-1952 yılları arasında göç eden Türklerin geride kalan aile üyelerini de birleştirmek amacıyla 1968 yılında Türkiye ile bir anlaşma yapma kararı almıştır. Todor Jivkov'un resmi Türkiye ziyareti ile imzalanan antlaşma sonucunda yaklaşık 115 bin Türk göç etmiştir. Bundan sonra BKP, 1969 yılında aldığı MYK kararında ilk defa Türkler için milli-kültürel özerklik tehdidi oluşturduklarından bahsetmiştir. Bu ifade sonraki yıllarda artan baskılara ve nihayetinde Türklerin isimlerini Bulgar isimleriyle değiştirilmesine kadar geçecek sürece dayanak noktası olmuştur. Bu tehdide karşı ilk etapta Bulgarca konuşan ancak Türk isimleri olan ve İslam dinine mensup Pomakların1970'li y1llarda isimlerini değiştirmek ile önlem alınmaya çalışılmıştır. Lokal direnişlerin olmasına rağmen genel anlamda başarılı geçen süreç Bulgar hükümetini cesaretlendirmiş ve Türk azınlığın da isimlerini başarıyla değiştirebileceğini düşünmüştür (Ivanova, 2007).

Pomaklara yönelik bu siyasi tutumun temel amacı ve kullanacakları yöntemlerden bazıları yıllar sonra ortaya çıkan 6 Mart 1964 tarihli BKP'nin MYK toplantısı tutanaklarında şu şekilde ifade bulmuştur: “..gündelik yaşantıda eski ve zararlı gelenekleri yok etmek..”; “..dini aşırıcıllğın üstesinden gelmek..”; “..Türk-Arap isimlerini Bulgar isimleri ile değiştirmek..” (Ivanova, 2002: 73-80). Ancak özellikle Ribnovo köyündeki Pomakların askeri merkez kurarak direnmesi, köyün ortasına Türk bayrağı çekmeleri ve ölümlü çatışmalara varan gerilim yüzünden Bulgaristan Komünist Partisi’nin bizatihi genel sekreteri olan Todor Jivkov kısa süreli de olsa geri adım atmak zorunda kalmış ve ilgili bölgedeki parti bürosu çalışanlarını hatalı metotlar kullanmakla suçlamıştır (Gruev ve Kalionski, 2008: 50-55; arşiv belgesi için bkz. TsDA, f. 1-b, op. 6, a.e. 5454, 1. 1-39). Buna rağmen izleyen yıllarda kademeli olarak Pomakların isimleri değiştirilmiş ve bu kısmi başarı BKP yöneticilerini sonraki adım için cesaretlendirmiştir.

Bulgaristan Halk Cumhuriyeti İçişleri Bakanı Dimitır Stoyanov'un tüm kolluk kuvvetlerine ve ilçe parti merkezlerine dağıttı bir genelgede "Türk soylu bütün Bulgar vatandaşlarının yeniden adlandırılması için hazırlıkların yapılması” emri verilmiştir (Vaksberg, 2001). Türk isimlerinin değiştirilmesine en üst makamda karar veren ise Todor Jivkov'un kendisi olmuştur. Uzun yıllardır edindiği tecrübesine dayanarak bu kararı kendi başına aldığı 1990 yılında tutuklandığında itiraf tutanaklarından anlaşılmaktadır. Ayrıca baş 
danışmanını Kostadin Chakarov'un hatıralarında Sovyetler Birliği'nin hiddetle karşı çıkması rağmen Todor Jivkov'un Türklere karşı bu politikayı uygulamada kararlı olması bunun blok kararı değil de ulusal bir karar olduğunun da göstergesidir (Drezov, 2001: 427). Bu süreçte resmi bir belgenin olmamasına ise özellikle çaba sarf edildiği sonradan anlaşılan bir hadise olmuştur. Todor Jivkov'un sözlü talimatı ile BKP yöneticisi Georgi Atanasov ve İçişleri Bakanı Dimitır Stoyanov olağanüstü yetkilerle harekete geçirilmiştir (Hristov, 2009).

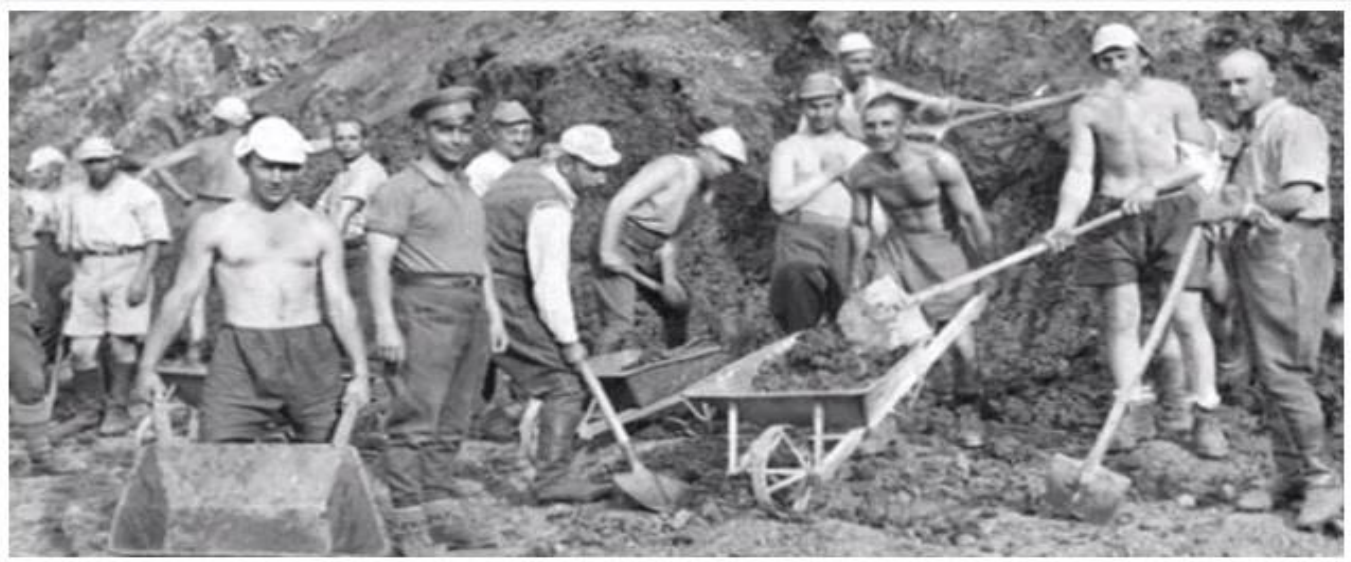

Лагерът Белене.

Resim 1. Belene Kamp1

Nihayetinde süreç 24 Aralık 1984'te başlayıp Şubat 1985 'te sona ermiştir. Sabah erken saatlerde başlayan çalışmalarda otomatik silahlar ile donatılmış kolluk kuvvetleri eşliğinde Türklerin çoğunlukta olduğu bütün il köylerine aynı anda baskınlar yapılmıştır. Silah zoruyla, Türklerin kendilerine gösterilen Bulgar isimleri arasından isim seçmeleri (!) istenmiş karşı çıkanlar fiziki şiddete maruz kalmıştır. Bu şekilde geçen ilk günden sonra, ertesi gün çeşitli köylerdeki Türk azınlıklar bir diğer köye geçerek belki orada daha yetkili birini bularak isimlerini geri alma umuduyla yollara dökülmüştür. Ancak köylerin etrafi kolluk güçleri ve askerler tarafindan kuşatılmış olduğundan geçmelerine müsaade edilmemiş. Israr edenlerin üzerine ise ateş açılmıştır. İlk ciddi olay Benkovski şehrinin yakınlarında meydana gelmiş 8 kişi ağır yaralanmış, 4 kişi ölmüştür. Ölenler arasında teyzesinin sırtında hiçbir şeyden habersiz başından vurulan bir buçuk yaşındaki Türkan adlı kız çocuğunun da olması Türkler arasında derin travma etkileri bırakmıştır. Günümüzde hâlâ o kız çocuğunun anısı canlı tutulmaktadır. Ülkenin diğer şehirlerinde de öldürülen Türkler olmuş, hapis cezası alan ve sürgüne gönderilenlerin sayısı da oldukça fazladır (Vaksberg, 2001). Bu olayda birçok kişi de tutuklanarak çok ağır fiziki işlerde çalıştırılmak ve hapiste tutulmak üzere kuzey Bulgaristan'da Tuna nehri üzerinde bulunan Belene adasındaki kampa gönderilmiştir (Koleva, 2012).

Çok kısa bir sürede yaklaşık 800 bin Türkün ismi değiştirilmiştir. Kampanya sonunda parti merkezine sunulan raporun bir ifadesi ise çok çarpıcıdır. Yapılan eylem şöyle tanımlanmıştır: "tarihi bir iş yapıldı, böylece milletimizin üzerinden Türk esaretinin bıraktığı son iz de kaldırılmış, Bulgarların isimleri geri alınmıştır”. İfadeden de anlaşılabileceği gibi aslında yapılan devlet propagandasında işlenen konu şöyledir: Osmanlı egemenliği döneminde esasında Bulgar olan kişilerin isimleri ve kültürleri baskı yoluyla ve asimilasyon ile değiştirilmiştir. Şimdi ise bunların geri alınması, tekrar Bulgar ulusunun diriltilmesi söz konusudur. Zira bu yüzden de bu sürecin adı Diriliş Sürecidir ("Vızroditelen Protses"). Kısaca yapılan eylem tamamen haklı ve doğru olduğu savunulmuştur. Böylece en üst siyasi erk tarafından yapılan zulmün psikolojik motivasyonu ortaya konularak yapılan asimilasyon eyleminin haklı bir tutum olduğu propagandası yaratılmaya çalışılmıştır (Angelov, 2008: 160-171).

Yukarıdaki verilen örnekler doğrultusunda süreç analiz edildiğinde Galtung modelinde insanın potansiyelini gerçekleştirmek ve yaşaması için temel gereklilikler arasından olan kimlik ihtiyacının çok bariz bir şekilde çiğnendiği görülmektedir. Bu olaylar dizisinde 800 bin kişinin kimliği zorla değişmesi, yüzlerce kişinin öldürülmesi, binlercesinin hapse atılması ve sürgüne gönderilmesi söz konusu olmuştur. Devletin aldığı bir karar neticesinde kolluk kuvvetleri ve devletin memurları emirleri uygulamıştır. Neticede Türk azınlığın kimlik ihtiyacı engellenerek kimliksiz kalmaları ve böylece Türklerin potansiyel gelişimlerinin çok 
altında kalmasına sebep olunmuştur. Ne yazık ki bu emrin geldiği asıl failin sübjektif kişisel sorumluluk bağlamında izinin sürülüp bulunması mümkün olmamıştır. Bu isim değişikliği birey üzerinde sistemsel bir etki olarak düşünülebilir. Ancak karşı çıkanların dövülmesi, saldırıya uğraması, işkence ve öldürmeye varan sonuçlarla karşılaşmaları neticesinde bireyin güvenlik ihtiyacının ve zorlama yöntemleri ile özgürlük ihtiyacının doğrudan engellenmesi de söz konusu olmuştur. Yukarıda bahsedilen kimlik ihtiyacına yönelik bu bariz şiddet durumu Galtung modeli bağlamında yapısal şiddet olarak değerlendirilebilir. Ancak Türk azınlığın güvenlik ihtiyacına yönelik fiziki saldırılar ve öldürme varan olaylar ile askerlerin ellerinde silahlar ile zorla imzalatılan yeni isim tercihleri (!) ise kişisel veya doğrudan şiddet olarak değerlendirilebilir, zira bu olaylarda genellikle tarihsel motivasyondan kaynaklı bireysel temelde memurların ve askerlerin aşırılıkları da olmuştur (Bayryamova, 2017).

Sonuç itibariyle ister yapısal ister kişisel şiddet olsun Türk azınlığın temel ihtiyaçları engellenmiş böylece potansiyel gelişim düzeylerine ulaşmaları bariz bir şekilde engellenmiştir.

$\mathrm{Bu}$ sürecin en önemli özelliklerinden birisi de her anlamda barış durumunun oluşmamış olmasıdır. Bir taraftan yapısal şiddet uygulamaları ile pozitif barışın sağlanma imkânı ortadan kalkarken diğer taraftan da doğrudan şiddet olayları (işkence, saldırı, öldürme vs.) ile negatif barış ortamı dahi oluşamamıştır. $\mathrm{Bu}$ bağlamda değerlendirildiğinde 1980'li yıllarının ortaları Türk azınlık için barışın olmadığı bir zaman dilimi olmuştur denilebilir.

Ayrıca bu dönemde Bulgaristan Halk Cumhuriyeti'nin Türk azınlığa yönelik uyguladığı politikalarla kendi aydın ve elit sınıfını dahi şaşırtmıştır. Bizatihi Bulgar aydın ve üst kademe siyasi elit arasında meydana gelen olaylardan rahatsız olan çok fazla insan olmuştur. Yapılan baskılar sadece isimlerin değişmesi ile kalmamıştır. Türklerin Türkçe konuşması, kendi kültürel (dini) faaliyetlerini yerine getirmeleri, kendi kültürüne uygun elbiselerin dahi giyilmesi yasaklanmıştır. Bu baskıların neticesinde 300 binden fazla Türk 1989 yılında sınır kapılarının açılması ile Türkiye’ye sı̆̆ınmıştır (Raychev ve Stoychev, 2008: 17).

Bulgaristan'ın o dönemde devlet eliyle uyguladığı baskılar öylesine aşırı bir noktaya ulaşmıştır ki birçok analist bu dönemde uygulanan baskıların kitlesel bir psikoz yarattığını söylemiştir. Bu ise Türklerin bir an önce ülkeyi terk etme isteğini çok güçlü bir şekilde motive etmiştir. Bulgar Komünist Partisi'nin (BKP) 7 Haziran 1989 yılındaki MYK toplantısı esnasında sunulan raporda bir "kitlesel psikozdan" bahsedilmesi bizzat devlet yönetiminin başkanı olan Todor Jivkov tarafından şu şekilde yorumlanmışır (Fetvadjieva, 2003: 86-87):

"Böyle bir psikozun oluşması bize lazımdı, şimdi bu hoş gelmiş, amacımız 200-300 bin kişinin göç etmesi aksi halde 15 yll içinde Bulgaristan diye bir şey olmaz veya Klbris gibi olur. Dolayısıyla biz bu olanları tehlikeli bir şey olarak görmüyoruz, aksine.. Türkler sinırı açacak mı - temel problem bu.. Kısaca göç meselesine olumlu bir olay olarak bakılmalıdır.."

$\mathrm{Bu}$ açıklamalardan da anlaşılabileceği gibi gerçek amacın sistemsel psikolojik bir baskı yaratarak bir kısım Türklerin gönüllü (!) bir şekilde göç etmesini sağlamak geriye kalanların da bir taraftan isimlerini değiştirerek diğer taraftan da kendi kültürlerini yasaklayarak korku atmosferi içinde asimile etmek. Yukarıda ifade bulan ve devlet yönetiminin açık bir şekilde düşüncelerini yansıtan arşiv belgesinden de anlaşılabileceği gibi Türklere yönelik yapısal şiddet çok bariz bir şekilde uygulandığı ortadadır. Doğal olarak bu şiddet durumu birçok kez fiziksel veya kişisel/dorudan şiddete de ulaşmıştır. Sonuç itibariyle Bulgaristan Komünist Partisi (BKP) döneminde hem negatif barış hem de pozitif barış durumları Bulgaristan'daki Türk azınlık için ortadan kalkmıştır.

\subsection{Soğuk Savaş Sonrası: Bulgaristan Cumhuriyeti ve Türkler}

Berlin duvarının yıkılması ile başlayan çözülme neticesinde Sovyetler Birliği’nin de dağılması Bulgaristan gibi komünist rejimin olduğu ülkeleri de değişime zorlamıştır. BKP 10 Ekim 1989 yılında yaptı̆̆ siyasi görüşmede artan uluslararası baskılar, kötüleşen ekonomi ve uluslararası sistemin dönüşümü gibi nedenler yüzünden Bulgaristan'da serbest piyasa ekonomisine geçiş mekanizmalarının başlatılması ve parti genel sekreteri (aynı zamanda devlet başkanı) olan Todor Jivkov’un görevden uzaklaştırılması kararlaştırılmıştır. Bu kararlar ülke için dönüm noktası olmuş zaten ondan sonra çok hızlı bir şekilde serbest 
piyasa ekonomisinin kuralları devreye girmiş ve on beş ay sonra da çok partili sisteme geçilmiştir (Jivkov, 1997: 618-628).

Dünyadaki değişimin baskıları Bulgaristan'da çok hızlı hissedilmiş ancak Bulgar ekonomisi ve siyasi yaşamı çok sancılı bir sürece girmiştir. Ülkenin birden bire kendini serbest piyasa ekonomisinde bulması plânlı ekonomi ile ürettiği malların dünya pazarında rekabet edememesine yol açmıştır. Devletin genel dış borcunun 10 milyar doların üzerine çıkması ve içerde enflasyonun hiper enflasyon seviyesine ulaşması ülke ekonomisini tamamen çökertmiştir. $\mathrm{Bu}$ ortamda siyasi partiler arasında iktidar mücadelesi ise zirve yapmıştır. Türk azınlığının da siyasi bir parti olarak organize olması Bulgar siyasi hayatında çok önemli bir yenilik olmuştur. İlk defa Türklerin çoğunlukta oldukları partiler kurulmuştur. Kısa zaman içinde Türk azınlık arasında da popülarite kazanan Türk partileri Bulgar siyasi hayatında ciddi kazanımlar elde etmiştir. $\mathrm{Bu}$ kazanımlar Türklerin normal hayatında siyasi, sosyoekonomik ve özgürlükler anlamında yansıma bulmuştur (Panov, 2014).

Çoğulcu siyasi hayata geçildiği seneyi izleyen yılda Türkler tarafından birçok kent merkezinde zorla değiştirilen isimlerin geri verilmesi için protestolar düzenlenmiştir. Bu taleplere olumlu cevap veren Bulgar devleti, eğer isterlerse Türklerin isimlerini geri almalarına kanuni hak vermiştir. Buna ilaveten her ne kadar Bulgaristan Halk Cumhuriyeti reddedilip Bulgaristan Cumhuriyeti kurulmuş olsa da yeni devlet eski komünist rejimin baskıları esnasında hayatlarını kaybeden, maddi ve manevi zararlara uğrayan mağdur kişi ve ailelere tazminat ödemeyi kabul etmiştir. Bulgaristan Cumhuriyeti eski rejimin zararlarını karşılamaya hazır olduğunu ifade etmekle sorumluluk halefliğine gitmiş böylece yapısal ve doğrudan şiddetin uygulandığını resmi olarak kabul ettiği anlamı çıkmaktadır. Elbette bütün bu gelişmelerin oluşmasında sadece Türklerin değil yeni siyasi ortamda çoğulcu siyasi düzenin ve uluslararası baskıların da katkısı büyük olmuştur (Jelyazkova, 1998).

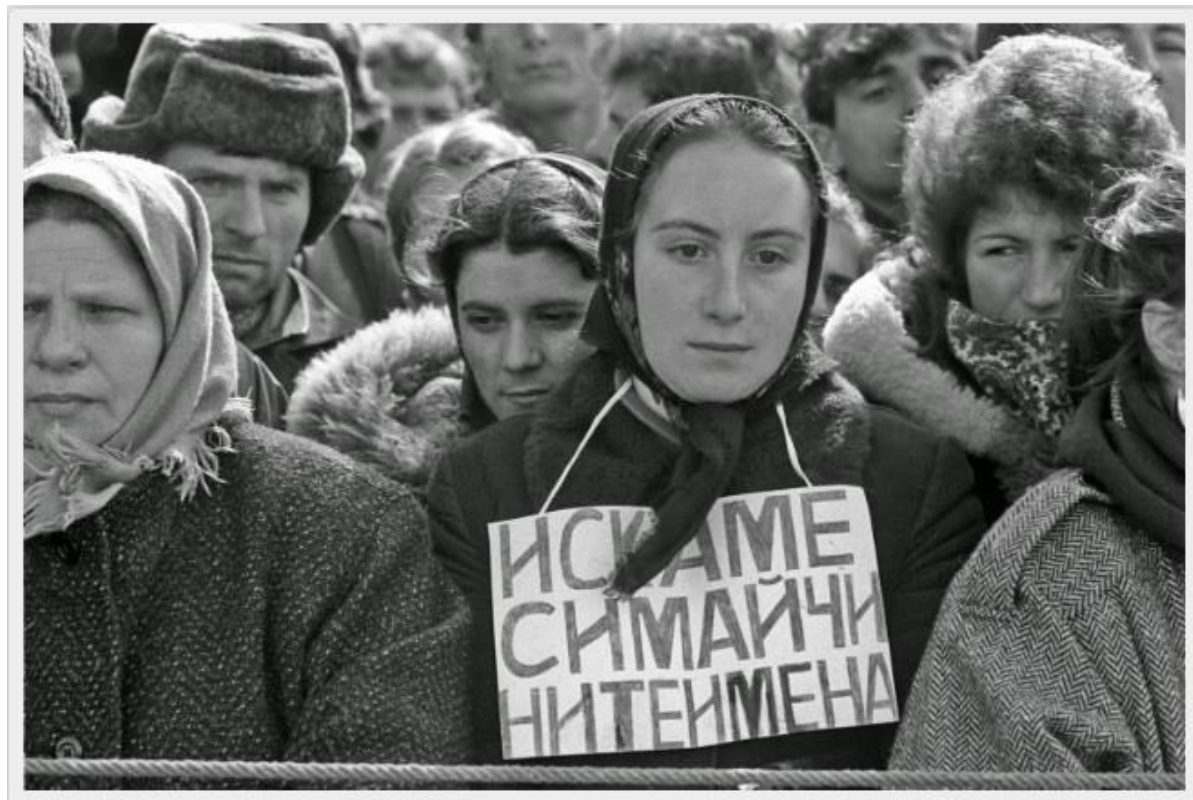

Resim 2. “Ana İsimlerimizi İstiyoruz” Pankartı Taşıyan Bir Türk Kadını

Her ne kadar bir dizi sorunun hâlâ devam ettiği bilinse de bu olumlu gelişmeler Galtung barış modeli bağlamında değerlendirilirse denilebilir ki, Türk azınlığın temel ihtiyaçları büyük oranda geri iade edilmiştir. Bunlar arasında en önemlileri siyasi hakların iadesi, kimlik ihtiyacının giderilmesi, sosyoekonomik statülerinin iyileşmesi gibi konular sıralanabilir. Bu hakların iade edilmesiyle birlikte diğer alanlardaki birçok engel de adım adım kaldırılmış ve kaldırılmaya da devam etmektedir. Türklerin birçok alanda meslek sahibi olmaları ve ticari kollarda aktif olmalarıyla refah düzeyleri de günden güne artmaktadır. Özellikle Bulgaristan'ın 2004 yılında NATO'ya ve 2007 yılında AB'ne girmesiyle birlikte temel ihtiyaçların sağlanmasında Türklere sunulan firsatlar artmıştır. Bu bağlamda siyasetten ekonomiye, sosyal toplum yapılarından kültürel alanlara kadar geniş bir yelpazede Türklerin varlığı görülmeye başlanmıştır. Bu açıdan analiz edildiğinde doğrudan şiddetin büyük oranlarda azaldığı hatta yok olduğu bile söylenebilir. 
Ancak özellikle yapısal şiddet bağlamında sorunların tam olarak ortadan kalktığını söylemek zordur. Özellikle Türklere karşı beslenen psikolojik olumsuz temeller gerek toplumsal seviyede gerekse siyasette devam ettiği gözlemlenebilmektedir. Ulusal bilinçte Türk azınlığa karşı olumsuz psikolojik duruşun varlığ 1 söz konusudur. Aynı sorunun sorulmasıyla üç yıl arka arkaya yapılan bir anketin sonuçları olumsuz bir psikolojik temelin varlığını göstermektedir. "Günlük hayatınızda kin ve nefret söylemlerinin muhatabı kim olmaktadır" sorusuna ankete katılanların \%58'i Türklere karşı kin ve nefret söylemlerini sürekli duyduklarını ifade etmişlerdir. Bu oran 2014'te \%39, 2016'da ise \%36 olmuştur. Bu anketin diğer ilginç bir noktası ise ankete katılanların \%8'i, nefret ve kin söylemini devlet memurlarından da duyduklarını ifade etmiş olmasıdır. Bu bağlamda düşünüldüğünde her ne kadar belli olmasa da devlet sistemi içinde yapısal şiddetin hâlâ devam ettiği sonucu çıkarılabilir (Ivanova, 2016: 13-16).

\section{SONUÇ}

Bu çalışmada Galtung'un yaklaşımı bağlamında Bulgaristan'daki Türk azınlığa yönelik uygulanan şiddet durumları analiz edilmiştir. Sonuç itibariyle görülmüştür ki, özellikle Soğuk Savaş döneminde Türk azınlığa karşı doğrudan şiddet dâhil açık ve bariz bir şekilde yapısal şiddet uygulanmıştır. Bunun neticesinde yüz binlerce Türk baskılardan kaçarak Türkiye'ye sığınmıştır. Bu dönemde bazı zamanlar müstesna tutulur ise Türklerin barış içinde yaşadıklarını söylemek çok zordur. Özellikle Türklerin isimlerinin değiştirildiği 1984-1985 yılları Türk azınlık için Bulgaristan tarihinde en zor zamanlardan birisi olmuştur bu dönemde yüzlerce Türk kasıtlı olarak veya baskı ve işkenceler sonucunda öldürülmüş, karşı çıkan binlerce Türk hapse atılmış, işkence görmüş ve ağır işlerde çalıştırılmak üzere Belene kampına gönderilmiştir. Türk azınlığın sadece isimleri değiştirilmek ile kalmamış bundan sonra da çeşitli baskılar devam etmiştir. Sokaklarda Türkçe konuşmak yasaklanmış, kültürel faaliyetlere izin verilmemiş, Türkçe neşriyatlar kapatılmış, dini semboller yasaklanmış ve dini mesuliyetlerin yerine getirilmesine müsaade edilmemiştir. Kısaca bu dönemde hem kişisel/doğrudan şiddet söz konusu olmuş hem de yapısal şiddet en güçlü ve bariz şekilde uygulanmıştır. Galtung'un kavramları ile ifade edilirse Türk azınlığın güvenlik ihtiyacı, refah ihtiyacı, kimlik ihtiyacı ve özgürlük ihtiyacı engellenerek yapısal ve doğrudan şiddet ile potansiyeline ulaşması engellenmiştir. "Vızroditelen Protses" (Diriliş Süreci) ifadesi, ideolojik anlamı itibariyle şunu ifade etmektedir - Türk azınlığın aslında Osmanlılar tarafından asimile edilmiş Bulgarlar olduklarını ve şimdi devletin ise bu vatandaşlarının gerçek Bulgar köklerini bulmalarına yardım ettiği veya onları dirilttiğidir. Ne var ki bu fikirsel önerme, aslında ülkedeki Türkleri ve Bulgar halkını ikna etmeyi amaçlayan belirgin bir propaganda aracı olmuştur. Galtung'un modeline göre, bir hatalı eylemin mantıksal sebepler göstererek doğruymuş gibi gösterilmeye çalışılması kültürel şiddetin en belirgin durumunu yansıtmaktadır. Bu bağlamda denilebilir ki, Bulgaristan Komünist Partisi'nin (BKP) siyasi iktidara hâkim olduğu dönemde Türkler için ne negatif barış ne de pozitif barış oluşmamıştır.

Soğuk Savaş sonrası dönemde BKP'nin lav edilmesiyle birlikte siyasi çoğulculuk ve serbest piyasa ekonomisine geçiş gerçekleşmiş bu dönemde doğrudan şiddetin ortadan kalktığı ve büyük oranlarda yapısal şiddetin de azaldığı görülmektedir. Bu dönemde Türklerin en önemli kazanımları siyasi haklarını kullanabilmeleri olmuştur. Türklerin siyasi partiler kurmalarına izin verilmesiyle birlikte diğer alanlarda da kazanımlar elde etmelerinin önü açılmıştır. Özellikle Bulgaristan'ın NATO ve AB'ne katılmasıyla yapısal şiddetin daha da azaldığı söylenebilir. Ancak yine de devam ettiğinin emareleri hâlâ vardır. Özellikle Bulgar ulusal bilincinde "öteki" olumsuz Türk algısı hâlâ devam ettiğinden buna bağlı olarak birçok alanda çeşitli engellemeler devam etmektedir. Bir genelleme yapılırsa denilebilir ki, bu dönemde negatif barış sağlanmıştır ancak pozitif barışın (ve sosyal adaletin) tam olarak sağlanması gerçekleşememiş̧ir. Ancak şurasını da belirtmek gerekir ki, pozitif barış yolunda ciddi ilerlemeler kaydedilmiş birçok alanda yapısal şiddet ya çok azalmış ya da ortadan kalkmıştır. 


\section{KAYNAKLAR}

ANGELOV, V. (2008), Strogo poveritelno! Asimilatorskata kampaniya sreshtu turskoto natsionalno maltsinstvo $v$ Bılgariya (1984-1989), Sofia: Simolini. [Çok Gizli! Bulgaristan'da Ulusal Türk Azınlığına Karşı Asimilasyon Kampanyasi (1984-1989)].

BAYRYAMOVA, V. (2017), Prestıplenieto ot 1984 g.,[1984 Yllındaki Suç], 20 Ocak 2019 tarihinde DW gazetesi: https://www.dw.com/bg/престьплението-наречено-възродителен-процес/a-18145623 adresinden alındı.

CHAKAROV, K. (2001), İstinata za Vizroditelniya Protses, [Diriliş Süreci Hakkındaki Gerçekler], 12 Ocak 2019 tarihinde Dünya Bugün gazetesi: https://worldtodaybg.com/2013/01/21/истината-за-възродителния- процес, adresinden alındı.

DIMITROV, B. (2006), 12 Mita v Bllgarskata Istoriya, Sofia: Fondatsiya Kom. [Bulgar Tarihinde 12 Mit].

DREZOV, K. (2001), Bulgaria and Macedonia: Voluntary Dependence on External Actors, J. ZIELONKA ve A. PRAVDA içinde Democratic Consolidation in Eastern Europe: International and Transitional Factors, (p. 413436), New York: Oxford University Press.

FETVADJIEVA, S. (ed.) (2003), Istinata za "Vizroditelniya Protses": Dokumenti ot arhiva na Politbyuro i TSK na $B K P$, Sofia: İnstitut za izsledvane na integratsiyata. ["Diriliş Süreci” Hakkında Gerçekler: BKP’nin MYK ve Politbüro Arşivinden Belgeler].

GALTUNG, J. (1969), Violence, Peace and Peace Research, Journal of Peace Research, (6)3, 167-191.

GALTUNG, J. (1990), Cultural Violence, Journal of Peace Research, (27)3, 291-305.

GRADEVA, R. (2001), Turtsite v Bılgarskata Knijnina XV-XVIII Vek, N.ARETOV ve N.CHERNOKOJEV içinde Balkanski İdentichnosti: V bilgarskata kultura ot modernata epoha (XIX-XX vek) (s. 112-134), Sofia: Fondatsiya Otvoreno Obshtestvo. [Bulgaristan Yazitlarında Türkler XV-XVIII y.y.]

GRUEV, M. ve KALIONSKI, A. (2008), Vizroditelen protses, Myusulmanskite obshtnosti i komunisticheskiyat rejim, Sofia: Siela. [Diriliş Süreci, Müslüman Topluluklar ve Komünist Rejim].

HEALEY, P. (1979), Basic Human Needs: The Politics of Mobilization, Tokyo: The United Nations University Press.

HILENDARSKI, P. (2004), İstoriya Slavyanobılgarska, Sofia: Kliment Ohridski. [Slav Bulgar Tarihi].

HRISTOV, H. (2009), Todor Jivkov. Biografiya, Sofia: Siela. [Todor Jivkov. Hayat Hikâyesi].

IVANOVA, E. (2002), Othvirlenite "priobshteni" ili protsestt, narechen "vizroditelen" (1912-1989), Sofia: İIEH. [Reddedilen "entegre edilmişler" ya da "diriliş" denilen süreç (1912-1989)].

IVANOVA, E.(2007), Ne e zadilititelno da se izvinyavate, gospodin ministre! [Sayın Bakan, özür dilemek mecburiyetinde değilsiniz!], 20 Ocak 2019 tarihinde Bulgaristan Helsinki Komitesi: http://www.bghelsinki.org/bg/publikacii/obektiv/evgeniia-ivanova/2007-03/ne-e-zadlzhitelno-da-se-izvinyavategospodin-ministre/ adresinden alındı.

IVANOVA, I. (2016), Obshtestveni Naglasi Spryamo Rechta Na Omrazata v Bilgaria Prez 2016 g., Sofia: Institut Otvoreno Obshtestvo. [2016 Yılında Bulgaristan'da Nefret Söylemine Karşı Toplumsal Tutum].

JELYAZKOVA, A. (1998), Sidbata na turskoto maltsinstvo v B1lgariya, Kultura, 2(2011). [Bulgaristan'daki Türk Azınlığın Kaderi].

JIVKOV, T. (1997), Memoari, Sofia: SIV. [Hatıralar].

KOLEVA, D. (2012), Belene: Remembering the Labour Camp and the History of Memory, Social History, (37)1, 1-18.

OGNYANOV, L. (2008), Politicheska sistema v Bilgariya 1949-1956, Sofia: Standart [Bulgaristan'da Siyasal Sistem].

PANOV, A. (2014), Yavlenieto DPS - 25 godini po k1sno!, Kultura, 43(2792). [DPS Fenomeni - 25 y1l sonra!], 25 Ocak 2019 tarihinde http://www.kultura.bg/bg/print_article/view/22891 adresinden alındı.

RAYCHEV, A. ve Stoychev, K. (2008), Kakvo se sluchi? Razkaz za prehoda v Bllgariya i za sled nego, Sofia: Trud. [Ne Oldu? Bulgaristan'da Geçiş Süreci ve Sonrası Hakkında Anlatım].

TsDA (Tsentralen Dırjaven Arhiv) f. 1-b. op. 6. a.e. 5454. L. 1-39. [Merkezi Devlet Arşivi].

VAKSBERG, T. (2001), Tehnologiya na zloto, SEGA [Kötülüğün Teknolojisi, SEGA Gazetesi], 22 Ocak 2019 tarihinde http://www.segabg.com/article.php?id=169176 adresinden alındı.

WEBEL, C. (ed.) ve GALTUNG, J. (ed.) (2007), Handbook of Peace and Conflict Studies, New York: Routledge. 